\title{
Hidden Interactions in the Economics of Peace and Conflict
}

Gearoid Millar

Institute for Conflict, Transition, and Peace Research

University of Aberdeen

g.millar@abdn.ac.uk

At a critical peacebuilding workshop in 2014, I presented findings from my ethnographic study of a bio-energy project in Sierra Leone, describing the unexpected economic impacts within local villages (see 2016, 2018a). Shortly afterwards, an economist attending the workshop stated - without apparent humour - that the challenge was to find out why people in these villages diverged from the economic models. For him, and many other economists, the problem lies not with the models, but with these strange people living outside the ordered rationality of homo-economicus. As Morten Jerven noted, economists "are now first and foremost interested in economics, not economies" $(2013,34)$, and the models, theories, and formulas are more important than close examination of how resources are distributed and deployed in real economies.

This problem is related to a methodological distancing between the scholars who study economics and the societies they study. The rise of the "neoclassical paradigm to unprecedented dominance in economic thought" (Dobusch and Kapeller 2012, 1035), has allowed economists to study economics largely from their desks, via quantitative data dislocated from everyday economic struggles that shape and bound lives within specific contexts or communities. To the extent that orthodox economics is uninterested in real economies, however, it is also unfit to contribute to understanding contemporary conflict and peace as contemporary conflict is hugely influenced by economic dynamics. This is, however, exactly where economic anthropology can be most useful, and particularly by contributing to peace and conflict studies and collaborating with scholars in that field.

By sheer coincidence I drafted this essay in the cities of Port Harcourt, Abuja, and Jos, during a series of interviews with local peacebuilders exploring past and future challenges to peace in Nigeria. A central theme of these discussions was the extent to which rampant poverty and the lack of gainful employment drive young people to become involved in violence. As others have described, such youth are easy targets for mobilization by elites when violent disruption is most advantageous for powerful actors (Watts 2007). These violence entrepreneurs are economic as well as political actors; the violence they encourage 
is both about controlling resources in order to access or maintain power, and about accessing or maintaining power in order to control resources.

Of course, this close interaction between power (politics) and resources (economics) is not new. When necessary, nations, states and empires have always deployed violent means for the protection of their economic interests; key, as they are, to maintaining power (Jhaveri 2004). And on these scales, of course, large-N quantitative research into the relationship between economics and violence - the forte of orthodox economists - are perfectly warranted. Indeed, such studies may suggest appropriate policy options for decreasing violence, ending conflict, and developing peaceful relations (Collier and Hoeffler 2002). However, contemporary conflict is not primarily waged at these scales. Violent conflict today is intra-state. It is distinctly sub-state, local and contextually situated (Kalyvas 2006).

Much like orthodox economics, Peace and Conflict Studies (PCS) has taken some time to adapt to this reality. While PCS is a broad field nourished by a range of disciplines, including anthropology, there is little doubt that as the field developed the role of states and international institutions became the primary concerns, positivist and quantitative approaches came to dominate the key journals, and issues of context and culture were relegated to the margins (Mac Ginty and Richmond 2013). In PCS too, therefore, economic dynamics were largely studied via state level metrics, as is evident the work of the Institute for Economics and Peace, for example. To a great extent the more localized and economic dynamics and the hidden concepts and expectations undergirding those dynamics within specific settings have been considered of secondary importance to conflict and peace (Millar 2014).

But it is, of course, exactly such very local dynamics - economic, social, and political - which disrupt formal peace settlements at the state level and undermine international peace interventions (Björkdahl et al. 2016). Deeply contextual and culturally distinct beliefs regarding conflict, violence and deprivation, as well as peace, security, and development shape expectations of the roles and responsibilities of authorities (whether local, national or international) and what conflict or peace should be (Cheater 1999). Exploring and understanding local motivations for involvement in conflict and peace, therefore, require longer-term engagement with and thick description of local cultures and communities; the opposite of the distancing associated with orthodox economics.

In response to this realization, the recent "local turn" in PCS scholarship has driven more recognition of the importance of culture and context (Mac Ginty and Richmond 2013), and introduced various constructs by which to better theorize about sub-national and locally specific dynamics of conflict and peace, such as "the everyday" (Mitchell 2011). But PCS is 
ill equipped methodologically to study such phenomena as it is dominated by scholars trained within Political Science and International Relations; disciplines with little tradition of ethnographic research, substantive engagement with local communities, or exploration of distinct beliefs, behaviours, norms and expectations. The field, therefore, has found it difficult to meet its own call for more robust engagement with local contexts.

It is in response to this challenge that economic anthropology can best contribute to the study of conflict and peace. Individual scholars can contribute by providing robust and grounded studies of the micro-economic drivers of conflict and peace in diverse cases, as has been accomplished by Paul Richards (1998), Carolyn Nordstrom (2004), or Alex de Waal (2015). Alternatively, anthropologists could collaborate with PCS scholars and practitioners to provide conceptual and methodological perspectives necessary for deep understanding of local contexts and cultures, as is exemplified, for example, in collaborative work by Coulter, Persson, and Utas (2008), or Peters and Richards (2007). It would also be hugely valuable to the field if economic anthropologists engaged with the ongoing effort to develop Ethnographic Peace Research (EPR) as a forceful agenda within the field (see Millar 2018b); helping, ideally to keep that effort theoretically and methodologically rigorous.

In short, there is a great need, within PCS, for engagement from anthropologists generally and, given the recognized contribution of economic dynamics to conflict at the local scale, from economic anthropologists in particular. Their contribution should be both theoretical and methodological, and take the form of both individual projects purely from an anthropological perspective, as well as collaborative efforts with interested PCS scholars. There is little doubt that economic anthropology could contribute substantially to our understanding of contemporary conflict and peace. But it is a challenge that requires time, energy and incentive from both sides to engage and share ideas, to explore opportunities and exclusions, and to develop shared and collaborative means of research and understanding.

\section{References}

Björkdahl, Annika, Kristine Hoglund, Gearoid Millar, Jair van der Lijn, and Willemijn Verkoren. 2016. Peacebuilding and Friction: Global and Local Encounters in Post Conflict Societies. London: Routledge.

Cheater, Angela. The Anthropology of Power. London: Routledge.

Collier, Paul, and Anke Hoeffler. 2002. "Aid, Policy and Peace: Reducing the Risks of Civil Conflict." Defence and Peace Economics 13(6): 435-450. 
Coulter, Chris, Mariam Persson, and Mats Utas. 2008. Young Female Fighters in African Wars: Conflict and its Consequences. Upsalla: The Nordic Africa Institute.

de Waal, Alex. 2015. The Real Politics of the Horn of Africa: Money, War and the Business of Power. Cambridge: Polity Press.

Dobusch, Leonhard, and Jakob Kapeller. 2012. "Heterodox United vs. Mainstream City? Sketching a Framework for Interested Pluralism in Economics." Journal of Economic Issues 46(4): 1035-1058.

Jerven, Morten. 2013. Poor Numbers: How We Are Misled by African Development Statistics and What to do About it. Ithaca: Cornell University Press.

Jhaveri, Nayna J. 2004. "Petroimperialism: US Oil Interests and the Iraq War." Antipode 36(1): 2-11.

Kalyvas, Stathis N. 2006. The Logic of Violence in Civil War. Cambridge: Cambridge University Press.

Mac Ginty, Roger, and Oliver P. Richmond. 2013. "The Local turn in Peace Building: A Critical Agenda for Peace." Third World Quarterly 34(5): 763-783.

Millar, Gearoid. 2014. "Disaggregating Hybridity: Why Hybrid Institutions do not Produce Predictable Experience of Peace.” Journal of Peace Research 51(4): 501-514.

Millar, Gearoid. 2016. "Local Experiences of the Liberal Peace: Marketization and Emerging Conflict Dynamics in Sierra Leone." Journal of Peace Research 53(4): 569-581.

Millar, Gearoid. 2018a. "Co-opting Authority and Privatizing Force in Rural Africa: Ensuring Corporate Power of Land and People." Rural Sociology 83(4): 749-771.

Millar, Gearoid. 2018b. Ethnographic Peace Research: Approaches and Tensions. Basingstoke: Palgrave.

Mitchell, Audra. 2011. "Quality/Control: International Peace Interventions and 'The Everyday"." Review of International Studies 37(4): 1623-1645.

Nordstrom, Carolyn. 2007. Global Outlaws: Crime, Money, and Power in the Contemporary World. Berkeley, CA: University of California Press.

Peters, Krijn, and Paul Richards. 2007. Understanding Recent African Wars. Africa 77(3): 442-454.

Richards, Paul. 1998. Fighting for the Rain Forest: War, Youth \& Resources in Sierra Leone. Portsmouth, NH: Heinemann.

Watts, Michael. 2007. "Petro-Insurgency or Criminal Syndicate? Conflict \& Violence in the Niger Delta." Review of African Political Economy 34(114): 637-660. 